\title{
Monitoring and modelling concept for ecological optimized harbour dredging and fine sediment disposal in large rivers
}

\author{
Marlene Haimann - Christoph Hauer - Michael Tritthart • \\ David Prenner $\cdot$ Patrick Leitner $\cdot$ Otto Moog $\cdot$ Helmut Habersack
}

Received: 3 August 2015/Revised: 28 July 2016/ Accepted: 31 July 2016/Published online: 14 September 2016

(C) The Author(s) 2016. This article is published with open access at Springerlink.com

\begin{abstract}
In this paper, a monitoring and modelling concept for ecological optimized harbour dredging and fine sediment disposal in large rivers is presented. According to the concept, first a preliminary assessment should be performed previous to the dredging and dumping procedure to derive knowledge about the current status in hydrodynamics, morphology and instream habitat quality. During the performance of the maintenance work, a high-resolution monitoring program has to be organized to measure flow velocities, the suspended sediment concentrations and the extent of the occurring plume. These data can then be compared with natural suspended sediment conditions
\end{abstract}

Guest editors: Helmut Habersack \& Roswitha Samek / Multifunctionality of large rivers

M. Haimann $(\varangle) \cdot$ C. Hauer · M. Tritthart .

D. Prenner $\cdot$ H. Habersack

Christian Doppler Laboratory for Advanced Methods in River Monitoring, Modelling and Engineering, Institute of Water Management, Hydrology and Hydraulic

Engineering, Department of Water, Atmosphere and Environment, BOKU - University of Natural Resources and Life Sciences, Vienna, Muthgasse 107, 1190 Vienna, Austria

e-mail: marlene.haimann@boku.ac.at

P. Leitner · O. Moog

Institute of Hydrobiology and Aquatic Ecosystem Management, Department of Water, Atmosphere and Environment, BOKU - University of Natural Resources and Life Sciences Vienna, Max-Emanuel-Strasse 17, 1180 Vienna, Austria and serve as input data for numerical sediment transport modelling. Furthermore, bathymetric surveys and biotic sampling enable the detection of possible effects of dredging and disposal in the postdumping stage. Based on sediment transport modelling approaches, short- to mid-term developments of the sediment plume can be predicted with an additional and final habitat evaluation at the end of the project. This concept was applied and optimized during the maintenance work at the case study winter harbour Linz at the Danube River. The findings of the presented study highlight the necessity of integrated monitoring and modelling approaches for harbour dredging especially in large river systems.

Keywords Harbour dredging - Fine sediment disposal $\cdot$ Monitoring and modelling concept $\cdot$ Danube River

\section{Introduction}

Sediments form a natural and integral component of fluvial systems and play an important part for the hydrological, geomorphological and ecological functioning of rivers. Whether material is transported as bedload or suspended load is determined by the relationship between flow conditions and the structure, density and size of the material, whereas fine (or clay and silt sized) sediments, formed by inorganic and 
organic particles, are likely to be transported in suspension (Owens et al., 2005). Suspended sediments form the main part of the transported sediments in rivers and are therefore of great interest for many sediment-related issues. Even in natural ecosystems, the suspended sediment concentrations and deposition rates are temporally and spatially variable depending on natural (e.g. seasonal changes in flow rates) (Ashmore \& Church, 2001) as well as human influences (e.g. reservoir construction/flushing or land use change) (Walling \& Fang, 2003) and the characteristics of the river system and corresponding catchment (Walling \& Webb, 1987; Walling, 2005). Thus, fish and other aquatic organisms have to adapt themselves to accommodate a range of sediment loads (Kemp et al., 2011). Nevertheless, elevated fine sediment loads may cause a variety of ecological problems (Kemp et al., 2011; Hauer, 2015).

High percentages of the total sediment load are usually transported in suspension during flood events in large rivers. Exemplarily, at the Austrian Danube, suspended sediments are trapped in the reservoirs of hydropower plants during low and mean flow conditions but are remobilized during floods (Reichel \& Nachtnebel, 1994), with suspended sediment concentration up to $15,000 \mathrm{mg} \mathrm{l}^{-1}$ (Nachtnebel et al., 2004). In the course of such events, extremely high sediment loads are flushed downstream and are partially deposited again in inundated areas (Prazan, 1990) or other areas of low flow velocities, such as inland harbours and harbour entrances. Consequently inland harbours, which are of great economic importance, are partly inaccessible for navigation. In particular cases, the harbour entrances are completely impassable and the shipment of goods therefore interrupted. The accessibility and navigability, however, should be guaranteed for the whole year at waterways, thus maintenance measures such as dredging have to be performed regularly (e.g. Darby \& Thorne, 1995; Hauschild, 2009). As most large rivers, which are frequently used for inland navigation, contain high suspended sediment loads during high-flow events (Prosser et al., 2001), a strong need exists for an increased understanding of the physical processes that occur during dredging and disposal of fine sediments. An increased process understanding, however, can only be achieved by high-resolution sampling techniques and integrated monitoring concepts for the design of future mitigation measures from both the technical and ecological perspective. In Austria, exemplarily, deposited material (formerly bed load or suspended load) in the Danube as one of the most important inland waterways in Europe has to be dredged by the Austrian waterway authority to maintain the functionality of harbours and to guarantee a minimum fairway depth for navigation. Generally, the dredged material is subsequently dumped into the main stream of the Danube River without any knowledge of possibilities for an interference of the ecosystem. Moreover, this dredging and dumping is done without any evidence if this measure is sustainable and what the consequences on the physical and biotic environment respectively are. This lack of information, however, has to be related to the lack of process understanding. Beside the missing quantification of impacts on the ecosystem [exceptions given by Moog et al. (2015)], a monitoring and sampling program evaluating harbour excavation and possible dredging of excavated material for large rivers is missing. Although several studies for monitoring (e.g. Fettweis et al., 2011; Cutroneo et al., 2013) and numerical modelling (Bai et al., 2003; Je et al., 2007; Mestres et al., 2014; Paarlberg et al., 2015) of excavation and dumping of fine sediments and the consequences on the aquatic fauna (e.g. Koel \& Stevenson, 2002; Wilber \& Clarke, 2001, 2007) have been published, only limited integrated monitoring concepts for large rivers have been discussed. Most published studies focused on estuaries and coastal areas, whereas these maintenance works in fluvial systems have rarely been investigated (Wilber \& Clarke, 2007).

Thus, an integrated monitoring and modelling concept (conceptual model) has been developed in the present study to address both technical and ecological issues in terms of harbour dredging. The aim of the process based sediment management concept is to enable optimized excavating and dumping strategies for inland harbours in large rivers. It is anticipated that the following steps are necessary to achieve the aim of a sustainable sediment management concept: (i) preliminary habitat studies, (ii) determination of the extent of the sediment plumes caused by dredging and dumping activities applying integrated monitoring techniques, (iii) comparison of the concentrations of the plume to naturally appearing concentrations in the river for discussing possible ecological impacts and (iv) verification of the 
application of a 2D/3D numerical model in the integrated monitoring concept to simulate and predict possible changes in the abiotic and biotic environment due to the induced sediment plume. The theoretical concept was tested and optimized based on a case study at the winter harbour Linz at the Austrian Danube.

\section{Materials and methods}

Conceptual model for an ecologically oriented harbour dredging

From an ecological perspective inland harbours have to be discussed in two different ways. From a hydraulic and morphological point of view, inland harbours provide different physical boundaries for aquatic ecology due to reduced flow velocities (backwater effects) similar to downstream connected side arms in non-regulated rivers. In large rivers used for inland navigation, such habitat types are often limited due to regulation of the main course based on crosssectional adjustments. In contrast to the possible minor habitat improvement of the physical components of a large regulated river, the water and sediment quality might be impaired due to industrial pollution, which is associated with the operation of an inland harbour. Both issues, the hydro-morphological status as well as sediment and water quality, have to be considered in terms of dredging and subsequent dumping of the dredged fine sediments.

Moreover, in the conceptual model (Fig. 1), detailed biotic and abiotic monitoring are required to determine the effects of sediment dredging and the dumping afterwards in the main channel. Highly accurate measurement techniques are needed to detect possible changes in bed morphology and thus possible impacts on hydraulics and the related instream habitats (e.g. on the micro-unit scale for target fish species). Moreover, continuous measuring techniques are required to record the extent of the dredge plume and changes in suspended sediment concentration, especially if critical thresholds for harmful impacts on aquatic ecology are exceeded during the event. In case of exceedance, the operations (dredging or dumping) have to be stopped. Moreover, tools for prediction and integrated evaluation have to be used in addition to onsite monitoring. Here, the application of numerical models is suggested to evaluate changes in hydrodynamics, sediment transport and morphology and the related instream habitats on various scales. For instance, numerical hydrodynamic models may be applied as tools for evaluation, scenario development and determination of the mid- to long-term consequences of dredging and material deposition. Based on the outcomes of the suggested monitoring and modelling strategy, the implementation and the ecological impacts of dredging and subsequent dumping can be evaluated, and parameters can be defined to be able to evaluate the temporal and spatial variability of processes in an ecologically oriented integrated management concept for inland harbour dredging and related sediment dumping in large rivers.

Monitoring methods and numerical models

For the conceptual model, an extensive monitoring program was conducted using acoustic devices, an echosounder and water samples to measure the suspended sediment concentrations and to detect the temporal and spatial extent of the plume caused by dumping the fine sediment. Furthermore, it was intended to provide input as well as calibration and validation data for the numerical hydrodynamic and sediment transport models for the application for short- to mid-term impacts of sediment dumping.

\section{Monitoring}

Flow velocity measurements As the flow velocity is one of the most important parameters that defines if a particle is kept in suspension or not (crucial for the processes of erosion and deposition), flow velocities were measured during the field campaign applying two different acoustic devices (Fig. 2a, b). Ultrasonic signals were emitted by the transducers, reflected by particles in the water, and the backscatter was registered by the device. The flow velocity is determined based on the shift of frequency between emitted and received signal. Here, an acoustic Doppler current profiler (ADCP), mounted on a vessel, measured the spatial distribution of the flow velocity along the river cross-section. The applied ADCP was operating at a frequency of $600 \mathrm{kHz}$ and had four acoustic beams at a $20^{\circ}$ orientation in relation to the instrument axis. To describe the ADCP profile depth (between 3 and $10 \mathrm{~m}$ ) with an appropriate vertical 


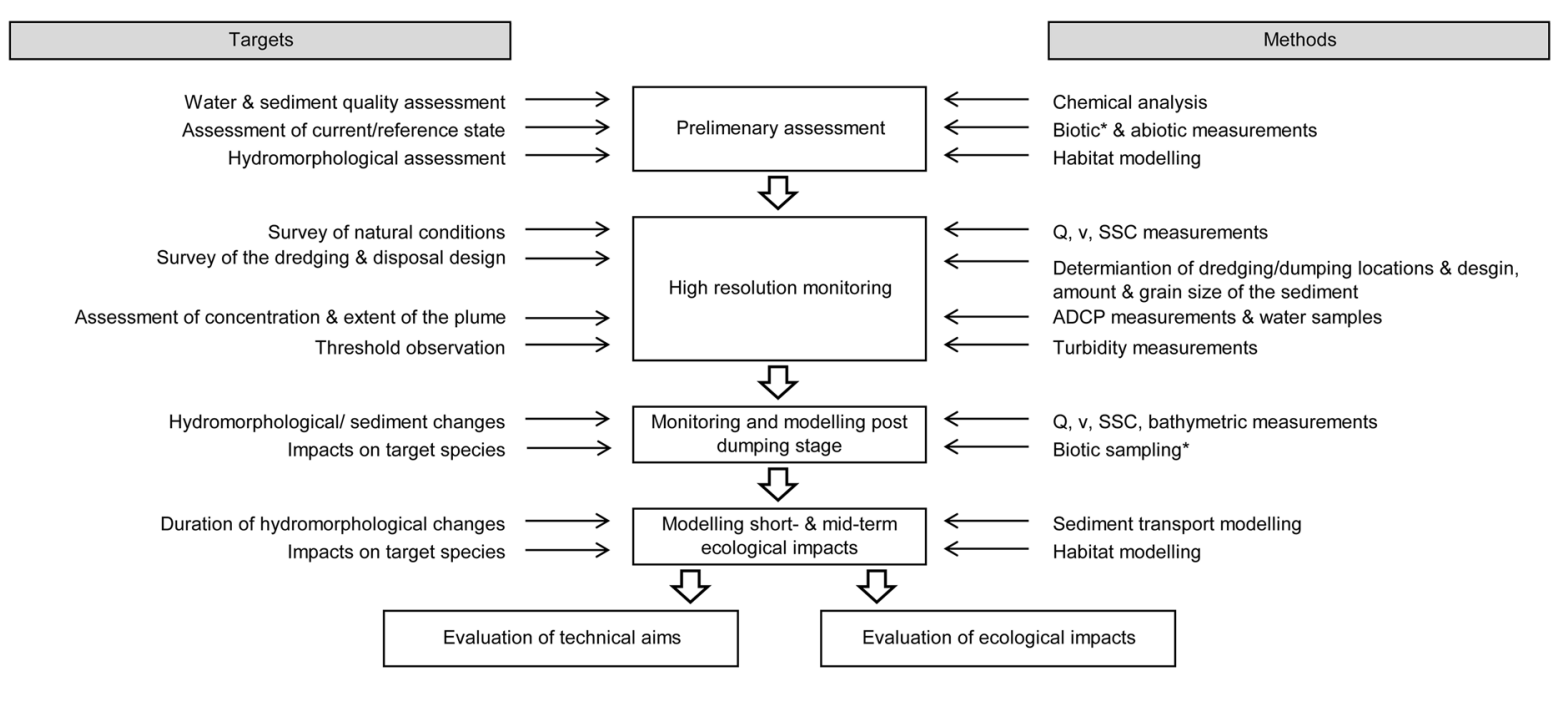

Fig. 1 Conceptual model for an ecologically oriented monitoring in terms of harbour dredging and downstream dumping of excavated sediments
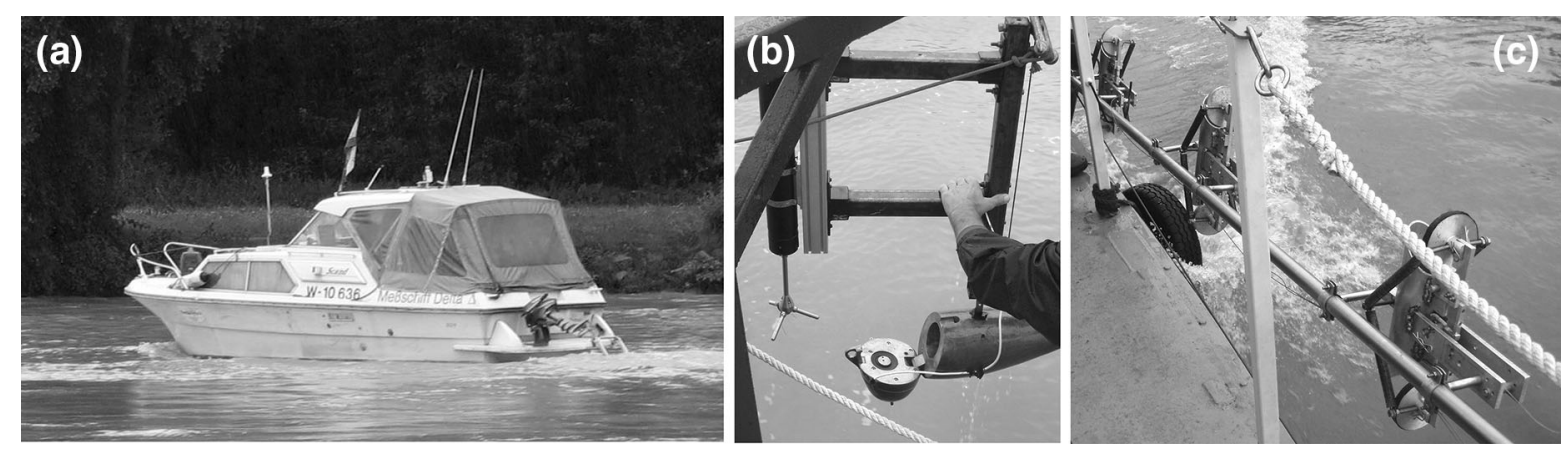

Fig. 2 Applied monitoring instruments: a ADCP vessel of viadonau, b ADV and US P-61 suspended sediment sampler, c IWHWsampler

resolution, a cell size of $0.25 \mathrm{~m}$ was selected. The applied ADCP has its limits when detecting the flow velocity near the banks, the surface or the river bed. Thus, additional measurements were performed during the field survey using an acoustic Doppler velocimeter (ADV), which was deployed suspended from the ship by a cable with the equipment mounted on a trailer (Fig. 2b), to detect the flow velocity near the river bed (distance from the river bed $<6 \%$ of the water depth). The ADV was operated at an acoustic frequency of $6 \mathrm{MHz}$ and a sampling rate of $64 \mathrm{~Hz}$. The sampling volume in a distance of $0.15 \mathrm{~m}$ from the probe had a diameter of $15 \mathrm{~mm}$ and a height of $14.9 \mathrm{~mm}$. Furthermore, the calibration of a multidimensional hydrodynamic model as a tool for prediction of short- and mid-term ecological impacts was performed based on the measured velocity data.

Suspended sediment monitoring The suspended sediment monitoring comprised the determination of the natural concentration of suspended sediments as well as the suspended sediment load caused by dredging and dumping of the fine material at the Danube River. Water samples were taken daily or even more often during flood events using a hand-held sampler on a pole from the river bank to measure the temporal variation of the natural concentration. The main focus was put on detecting the suspended sediment concentration caused by the dredging and dumping of the fine material. As the signal emitted by 
ADCPs is reflected by the particles in the water, the suspended sediment concentration can be estimated from the backscatter intensity (e.g. Guerrero et al., 2016), using the sonar equation formulated as a working version by Deines (1999), which describes a balance of the acoustic pulse from the emission at the transducer until its registration including the lost energy (Eq. 1).

$S_{v}=C+10 \log _{10}\left[\frac{T_{T} R^{2}}{L P_{T}}\right]+2 \alpha R+K_{c}\left(E-E_{r}\right)$,

where $S_{v}$ is the backscattering strength, $C$ a constant, $T_{\mathrm{T}}$ the temperature of the transducer, $R$ the range along the beam (slant range) to the scatterers, $L$ the transmit pulse length, $P_{\mathrm{T}}$ the transmit power, $\alpha$ an attenuation coefficient, $K_{\mathrm{c}}$ a scale factor, $E$ the relative backscatter equal to echo intensity and $E_{\mathrm{r}}$ the received noise. The attenuation coefficient $\alpha$ is the sum of water absorption $\left(\alpha_{\mathrm{w}}\right)$ and particle attenuation $\left(\alpha_{\mathrm{s}}\right)$ summarized in Francois and Garrison (1982a, b) and Urick (1948), respectively (Aardom, 2006).

This method was already used to detect the suspended sediment concentration in the Danube River (Reichel \& Nachtnebel, 1994; Baranya \& Józsa, 2013) and to measure the suspended sediment plume caused by dredging and dumping operations of fine material at Tylers Beach in Virginia (Thevenot et al., 1992) and in the Baltic Sea near Rügen (Maushake, 2008). In the presented case, the device was used in a similar way, i.e. detection of the spatial distribution of the plume for cross- and longitudinal sections. Additionally, the temporal distribution of the suspended sediment concentration caused by dumping of the material was observed by measuring the passing plume at a fixed position (river-km 2,131.4 and 2,131.5). Moreover, for the purpose of calibrating the signals, samples were taken at 1,2 and $3 \mathrm{~m}$ depth applying the IWHW-sampler (Habersack et al., 2000) (Fig. 2c). The relationship between backscatter intensity and suspended sediment concentration was calibrated separately for each of the eight dumping operations. As it was not possible to detect the suspended sediment concentration at the lowest $6 \%$ of the water depth with the ADCP device, additional samples were taken close to the river bed using an US P-61 suspended sediment sampler (Edwards \& Glysson, 1999) (Fig. 2b). By applying a US P-61 suspended sediment sampler as well as the IWHWsampler, the isokinetic extraction of the sample was ensured. The suspended sediment concentration of all water samples was analysed in the lab by vacuum filtration using cellulose filters with pore diameters of $0.45 \mu \mathrm{m}$. To determine the grain size distribution of the dredged fines, a representative amount of the material was taken from each barge. Furthermore, samples of the Danube bed material were taken to determine the grain size distributions. The granulometric analyses were conducted using sieving methods (grain size $>20 \mu \mathrm{m}$ ) and X-ray sedimentation method (Sedigraph) for the fine fractions.

Bathymetric survey The data of the morphological changes of the river bed were measured, using a multibeam echosounder, and processed by viadonau, the Austrian waterway authority. The provided dataset for determining river bed changes contained a bathymetric resolution of $1 \mathrm{~m}$ in the planimetric view. At the dredging site, the dimensions of the dredged area were mapped, and in the main stream of the Danube River (river-km 2,131.0-2,131.75), measurements were performed to determine if morphological changes occur due to aggradation of dumped material at the river bed. These surveys were conducted before the maintenance work was started and in the evenings after completion of the works.

\section{Numerical modelling}

Hydrodynamic model description The flow field of the investigated Danube reach in Austria was obtained with the model River Simulation 3D (RSim-3D) (Tritthart, 2005; Tritthart \& Gutknecht, 2007). It provides concurrent solutions of the three momentum equations (Reynolds equations, Eq. 2), the continuity equation and two equations for modelling the turbulence. These governing equations are solved by application of the finite volume method on a mesh based on polyhedral cells with predominantly hexagonal base shapes.

$\overline{u_{i}} \frac{\partial \overline{u_{i}}}{\partial x_{i}}=-\frac{1}{\rho} \frac{\partial \bar{p}}{\partial x_{i}}-\frac{\partial \overline{u_{i}^{\prime} u_{j}^{\prime}}}{\partial x_{j}}+v \frac{\partial^{2} \overline{u_{i}}}{\partial x_{j}^{2}}+S$,

where $u_{i}$ indicates the mean flow velocity in each spatial dimension $x_{i}, p$ the pressure in a cell, $\rho$ the density, $\overline{u_{i}^{\prime}}$ the mean turbulent fluctuations (Reynolds 
stresses), $t$ the time, $v$ the kinematic viscosity and $S$ the source term accounting for external forces acting on the fluid (Tritthart \& Gutknecht, 2007). Variables denoted by an overbar are time-averaged, while those with a prime sign are instantaneous, fluctuating components.

The pressure distribution in the model is nonhydrostatic; the pressure field is linked to the flow field by the SIMPLE algorithm (Patankar \& Spalding, 1972). For turbulence modelling, the hydrodynamic model can be run with either the standard $k-\varepsilon$ or several variations of the $k-\omega$ model; in this study, the standard $k-\varepsilon$ model was used. At the wall, a no-slip condition (zero velocity) is enforced, with the velocity at the first node in the flow continuum being estimated from a logarithmic velocity profile that relies on a usersupplied absolute wall roughness, which is subject to model calibration. Turbulence and dissipation values for the near-wall node are calculated from empirical relationships (Tritthart, 2005). The model calculates upstream flow velocities from a given discharge value, while downstream a known water surface boundary condition is applied. The position of the free water surface in all other regions of the numerical mesh is obtained by iteratively translating a pressure surplus or deficit at the surface into water level changes.

Habitat modelling Instream habitat modelling was conducted in a preliminary assessment and postevaluation of the project, respectively. Here, the mesohabitat description and quantification was done by the mesohabitat evaluation model (MEM). The conceptual MEM model was developed by Hauer et al. (2009) and enables the evaluation of six different mesohabitats according to their abiotic characteristics. In the MEM analysis, three abiotic parameters (flow velocity, water depth and bottom shear stress) were incorporated. First, depth-averaged velocity $\left(\mathrm{m} \mathrm{s}^{-1}\right)$ and water depth $(\mathrm{m})$ are selected and divided into five classes (according to the range of values). This yields specific velocity depth relationships at each node of the modelling mesh. In a second step of the modelling approach, the velocity-depth relationships are weighted by three classes of bottom shear stress (energy potential), allowing six statistically different mesohabitat types to be distinguished (Hauer et al., 2009). Riffles and fast runs are classified as high energetic (high bottom shear stress), run and pool as moderate energetic and backwaters and/or shallow water habitats as low-energetic hydromorphological units. For practical purposes, the MEM concept was implemented into a Java software application which enables MEM evaluation based on one of three different two-dimensional models (CCHE2D, River2D, Hydro_AS-2D) and two different threedimensional models (RSim-3D, SSIIM). Loading multiple result files at the same time enables habitat evaluations for different discharges as well as unsteady flow simulations (Tritthart et al., 2008). Within this case study, mesohabitats were mapped graphically and, in addition, quantified by area $\left(\mathrm{m}^{2}\right)$ and evaluated in relation to the total wetted area $(\%)$.

Sediment transport modelling For modelling sediment transport and morphodynamics, the integrated sediment transport model (iSed) (Tritthart et al., 2009, 2011) was applied. For simulating the sediment transport, not only sediment but also hydrodynamic properties (bed shear stress, flow velocities and water depth) have to be considered. The integrated sediment transport model iSed does not calculate these parameters but obtains them from an external hydrodynamic model. As the model iSed acknowledges various mesh types, it can be coupled with various numerical models of different dimensionality (2D or 3D).

Within the model iSed, the suspended load and the bedload can be calculated separately but as the results of grain size analyses revealed a very fine grain size of the excavated material $(d<0.2 \mathrm{~mm})$ only the suspended sediment transport was of interest for this investigation and therefore considered within the simulations. The transport of suspended sediments is described by a convection-diffusion equation (Eq. 3), extended by a term capturing the interaction with bed material, and is solved separately for each grain size fraction.

$$
\begin{aligned}
\frac{\partial c}{\partial t} & +\frac{\partial\left(u_{1} c\right)}{\partial x_{1}}+\frac{\partial\left(u_{2} c\right)}{\partial x_{2}} \\
& =\frac{\partial}{\partial x_{1}}\left(K_{t} \frac{\partial c}{\partial x_{1}}\right)+\frac{\partial}{\partial x_{2}}\left(K_{t} \frac{\partial c}{\partial x_{2}}\right)+\left(s_{\text {dep }}-s_{\text {ero }}\right)
\end{aligned}
$$

where $c$ is the depth-averaged suspended sediment concentration, $u_{i}$ the flow velocities in the corresponding coordinate directions $x_{i}, K_{t}$ is a depth-averaged diffusion coefficient estimated from Eq. 4 and $t$ is 
time. $s_{\mathrm{dep}}$ is the deposition flux and $s_{\text {ero }}$ is the erosion flux, calculated after van Rijn (1984) and Garcia \& Parker (1991), respectively.

The depth-averaged diffusion coefficient for every node is calculated from:

$K_{t}=\frac{1}{6} h u^{*} \kappa$,

where $h$ is water depth, $\kappa$ von Karman's constant ( $\kappa=0.41)$ and $u^{*}$ the shear velocity at the bed, computed from the bed shear stress delivered by the hydrodynamic model.

For every time step of an unsteady hydrograph, first the hydrodynamic model is called, which solves Eq. 2. Then, for the same time step, Eq. 3 is solved in the iSed model using the flow field and bed shear stress previously provided by the hydrodynamic model. When coupled with a 3D hydrodynamic model, the flow velocities $u_{i}$ in the two horizontal coordinate directions are obtained from depth-averaging the three-dimensional flow field.

\section{Study reach}

The theoretical concept was applied in a case study at the harbour "Winterhafen Linz" (N48 $19^{\prime} 08^{\prime \prime}$, E14 $\left.{ }^{\circ} 18^{\prime} 54^{\prime \prime}\right)$ situated at river-km 2,131.9 on the orographic right-hand side (south) of the Danube River (Fig. 3). In this reach, the Danube River has a width of about $250 \mathrm{~m}$ and riprap protected banks. The study reach is located about $12 \mathrm{~km}$ upstream of the hydropower plant Abwinden-Asten (river-km 2,119.5) resulting in increasing mean water depths from $6.4 \mathrm{~m}$ (at river-km 2,133.0) to $9.0 \mathrm{~m}$ (at river-km 2,130.1) at mean flow and lower flow velocities in the downstream part of the study area. The slope of the water surface in this area is about $0.07 \%$, and the hydrology at this reach is characterized by a regulated low flow of $680 \mathrm{~m}^{3} \mathrm{~s}^{-1}$ and a mean flow of $1,480 \mathrm{~m}^{3} \mathrm{~s}^{-1}$. In this reach, the Danube River is classified as a gravel bed river with an arithmetic mean sediment diameter of $d_{\mathrm{m}}=23.3 \mathrm{~mm}$, a $d_{10}=2.1 \mathrm{~mm}$ and a $d_{90}=58.0 \mathrm{~mm}$. According to Nachtnebel et al. (2004), the mean suspended sediment concentration amounts to approximately $45 \mathrm{mg} \mathrm{l}^{-1}$ at the Austrian Danube River.

For preliminary habitat studies as well as modelling the deposition of the excavated material and the resulting suspended sediment plume, a reach of $1.5 \mathrm{~km}$ was investigated, ranging from river-km $2,130.5$ to $2,132.0$ (flow direction is from NW to $\mathrm{SE})$. To reduce disturbances originating from estimated boundary conditions additionally, an approaching section of $1000 \mathrm{~m}$ (as the upper boundary is situated in a river bend) and a trailing section of $500 \mathrm{~m}$ were provided, totalling a simulated length of $3 \mathrm{~km}$ (from river-km 2,130.0 to 2,133.0). At the upstream boundary, a constant discharge was used and the flow velocity was estimated based on the given discharge applying a uniform velocity distribution using the approaching section to form a natural velocity profile.
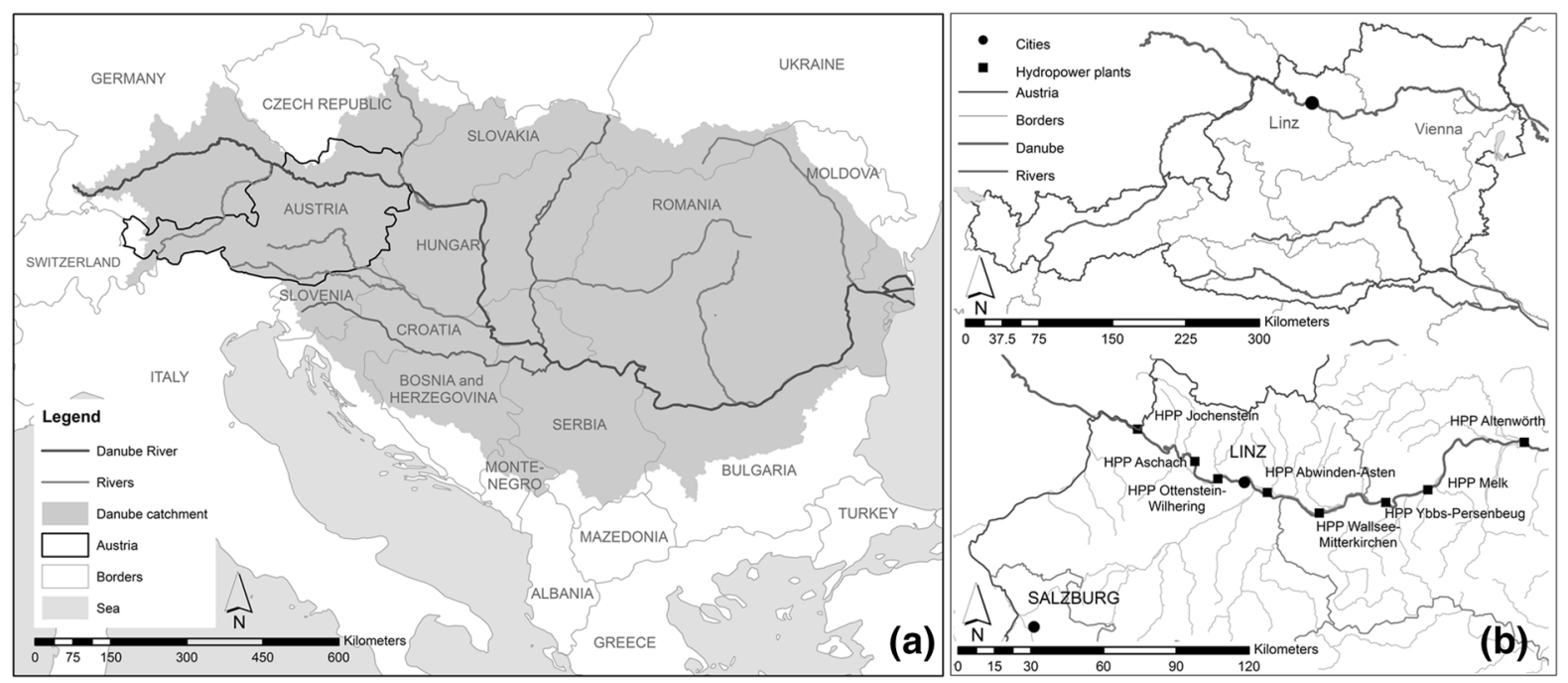

Fig. 3 a Catchment of the Danube River and b location of the project site Winter harbour Linz at the Austrian Danube 
Fixed water levels, estimated from the characteristic water levels of the Danube River [Kennzeichnende Wasserstände der Donau KWD (Austrian Federal Waterways Authority, 1997)], were defined at the downstream boundary. The horizontal spacing of the computational mesh amounted to $10 \mathrm{~m}$ in the centre of the river and $7 \mathrm{~m}$ near the banks as well as in the harbour regions. In the vertical, six depth layers were applied, resulting in a total of 89,000 cells in 3D. The hydrodynamic model was calibrated for mean discharge conditions (MQ $=1,480 \mathrm{~m}^{3} \mathrm{~s}^{-1}$ ) and validated for $1,000 \mathrm{~m}^{3} \mathrm{~s}^{-1}$ as well as $2,375 \mathrm{~m}^{3} \mathrm{~s}^{-1}$ (discharge during dredging and disposal) on measurements of flow velocities (Fig. 4) and water surface elevations. As result of the model calibration, the absolute roughness height was found to take a value of $k_{\mathrm{s}}=0.15 \mathrm{~m}$ for the river bed and a value of $k_{\mathrm{s}}=0.30 \mathrm{~m}$ for the embankments.

The model of the winter harbour Linz concerning water depth and mean flow velocities at a discharge of 2,375 $\mathrm{m}^{3} \mathrm{~s}^{-1}$ are depicted in Figs. 5 and 6, wherein the influence of the downstream reservoir (hydropower plant Abwinden-Asten, Fig. 3) is apparent from the increasing water depths and lower flow velocities in downstream part of the study area.

The sediment transport model iSed was run for 23 grain size classes, ranging from 0.0002 to $230 \mathrm{~mm}$, according to the grain size distribution of the dredged
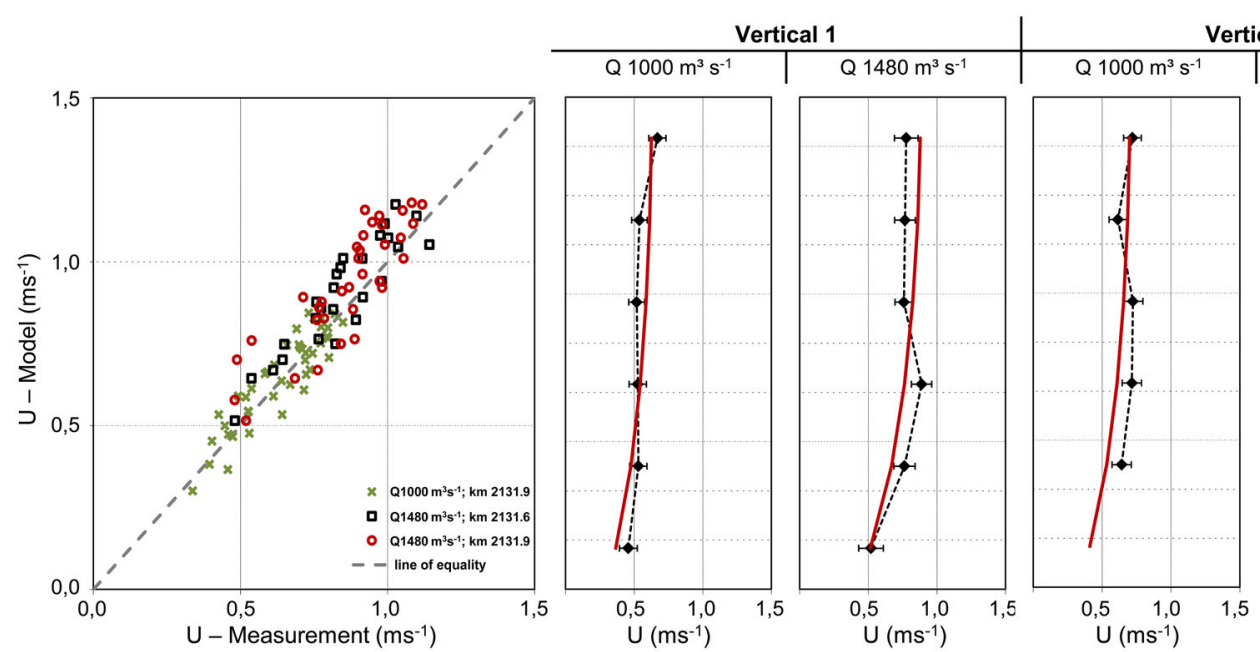

ertical 2
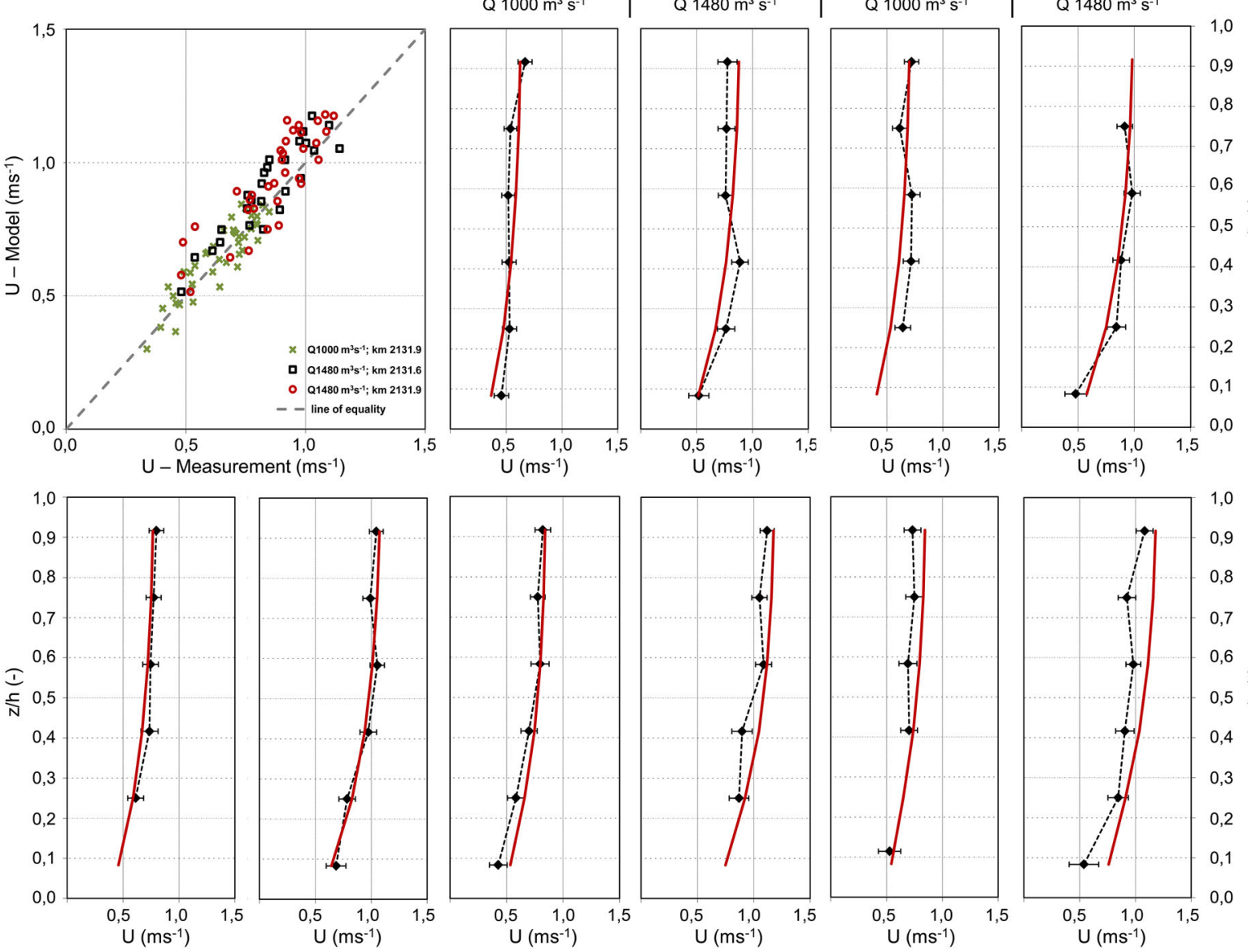

\section{$\frac{\text { I }}{\text { ก }}$}

\begin{tabular}{c|c|c|c|c|c} 
Q $1000 \mathrm{~m}^{3} \mathrm{~s}^{-1}$ & Q $1480 \mathrm{~m}^{3} \mathrm{~s}^{-1}$ & Q $1000 \mathrm{~m}^{3} \mathrm{~s}^{-1}$ & Q $1480 \mathrm{~m}^{3} \mathrm{~s}^{-1}$ & Q 1000 $\mathrm{m}^{3} \mathrm{~s}^{-1}$ & ${\mathrm{Q} 1480 \mathrm{~m}^{3} \mathrm{~s}^{-1}}^{\text {Vertical 4 }}$ \\
\hline
\end{tabular}

Fig. 4 Scatter plot: comparison between monitored (ADV) and modelled flow velocities at river-km 2,131.9 at a discharge of 1,480 (red circles) and $1,000 \mathrm{~m}^{3} \mathrm{~s}^{-1}$ (green crosses) as well as at river-km 2,131.6 at a discharge of $1,480 \mathrm{~m}^{3} \mathrm{~s}^{-1}$ (black squares); Comparison in five verticals between monitored (ADV) (black dots) and modelled (red lines) flow velocities at a discharge of 1,480 and $1,000 \mathrm{~m}^{3} \mathrm{~s}^{-1}$ at river-km 2,131.9 


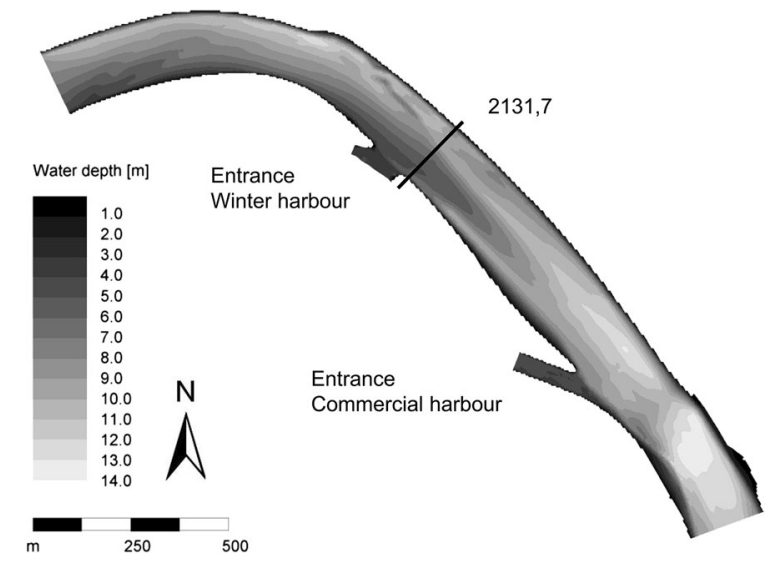

Fig. 5 Modelled water depth at a discharge of $2,375 \mathrm{~m}^{3} \mathrm{~s}^{-1}$ and illustration of the simulated dumping location at river-km $2,131.7$

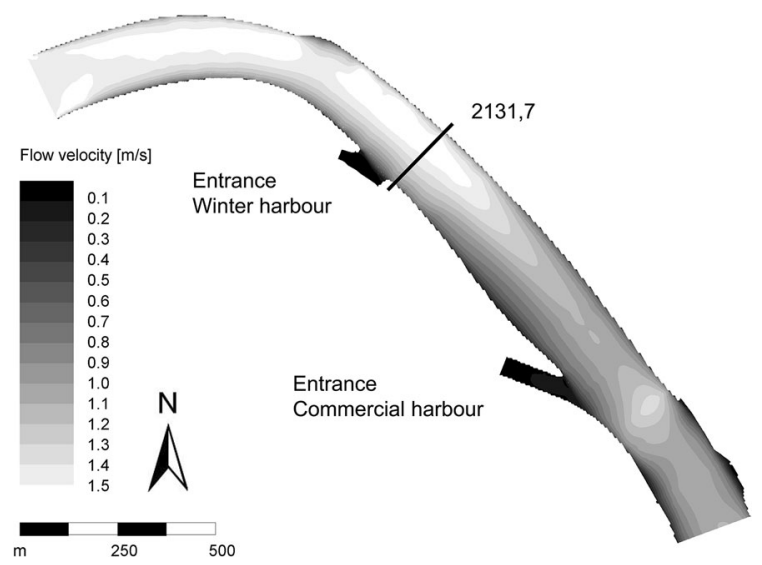

Fig. 6 Modelled mean flow velocity at a discharge of $2,375 \mathrm{~m}^{3}$ $\mathrm{s}^{-1}$ and illustration of the simulated dumping location at river$\mathrm{km} 2,131.7$

material in combination with the grading curve of the river bed sediment. However, the convection-diffusion equation for suspended sediment is not evaluated for grain sizes larger than $1 \mathrm{~mm}$, which is why finally a total of 9 grain size classes $(<0.0002,<0.0006,<0.002$, $<0.0063,<0.02,<0.063,<0.2,<0.25$ and $<0.5 \mathrm{~mm}$ ) were considered by the model for transport in suspension.

\section{Results}

Preliminary assessment

The first step of the preliminary assessment before excavating material in an inland harbour is to derive basic knowledge about the current status in hydrodynamics, morphology and instream habitat quality. Here, numerical modelling is applied for the first time concerning the scope of the conceptual model (Fig. 1). Preliminary habitat modelling enables the identification of ecologically sensitive reaches and bottleneck habitats where dredged material should not be deposited.

The habitats in the investigated Danube reach have been evaluated based on the MEM concept for two different discharges $\left(Q=680 \mathrm{~m}^{3} \mathrm{~s}^{-1} / Q=2,375\right.$ $\left.\mathrm{m}^{3} \mathrm{~s}^{-1}\right)$. Mesohabitats $(n=6)$ were calibrated according to the MEM concept (Hauer et al., 2009). The thresholds for water depth $(\mathrm{m})$, flow velocity $\left(\mathrm{m} \mathrm{s}^{-1}\right)$ and bottom shear stress $\left(\mathrm{N} \mathrm{m}^{-2}\right)$ were determined according to one-dimensional modelling results in a near natural stretch of the Danube (Hauer et al., 2011). The calibrated thresholds for mesohabitat classification are shown in Table 1. The determination of abiotic riffle characteristics for this large river involved historical analysis (e.g. Hohensinner et al., 2004). This was necessary because the natural shape of riffle habitats is continuously modified (e.g. dredging) by requirements of especially inland navigation. For the investigated river stretch of the Danube, however, riffle habitat characteristics (water depth $<1.0 \mathrm{~m}$, flow velocity $>1.0 \mathrm{~m} \mathrm{~s}^{-1}$ and bottom shear stress $>15 \mathrm{~N} \mathrm{~m}^{-2}$ ) were not found in the entire modelling reach. Riffle habitat characteristics (e.g. head of gravel bars), however, would be important as they are well known for providing suitable spawning habitats for the target fish species of rheophilic cyprinids (Chondrostoma nasus, Barbus barbus) at the Danube (Zauner et al., 2001). In addition, the MEM modelling results exhibited important key habitats like shallow water and backwater sites (Fig. 7) which can be seen as crucial rearing or refugial habitat for most of the juvenile fish in terms of natural fluctuating flows.

The results are presented in Fig. 7 and highlight a clear change in the distribution of hydromorphological units between low and high flow. This preliminary assessment, as part of the conceptual model for ecological optimized harbour dredging, was of special importance to derive quantitative data of the ecological status (theoretically suitable habitats) before the excavation has taken place. Based on the applied modelling approach, it was possible to show the general poor habitat heterogeneity in the study reach 
Table 1 Classification of velocity $\left(\mathrm{m} \mathrm{s}^{-1}\right)$, depth $(\mathrm{m})$ and bottom shear stress $\left(\mathrm{N} \mathrm{m}^{-2}\right)$ for the Danube river related to various hydromorphological units (MEM concept) evaluated for low flow $\left(Q_{\mathrm{L}}\right)$

\begin{tabular}{ccccccc}
\hline & Riffle (I) & Fast run (II) & Run (III) & Pool (IV) & Backwater (V) & Shallow water (VI) \\
\hline$d$ & $<1.00$ & $>1.00$ & $>0.01$ & $>1.80$ & $>1.00$ & $<1.00$ \\
$v$ & $>1.00$ & $>0.75$ & $>0.25$ & $<0.50$ & $<0.25$ & $<0.25$ \\
$\tau$ & $>15.00$ & $>15.00$ & $0.50-15.00$ & $0.50-15.00$ & $<0.50$ & $<0.50$ \\
\hline
\end{tabular}

$d$ depth $(\mathrm{m}), v$ velocity $\left(\mathrm{m} \mathrm{s}^{-1}\right), \tau$ shear stress $\left(\mathrm{N} \mathrm{m}^{-2}\right)$

(a)

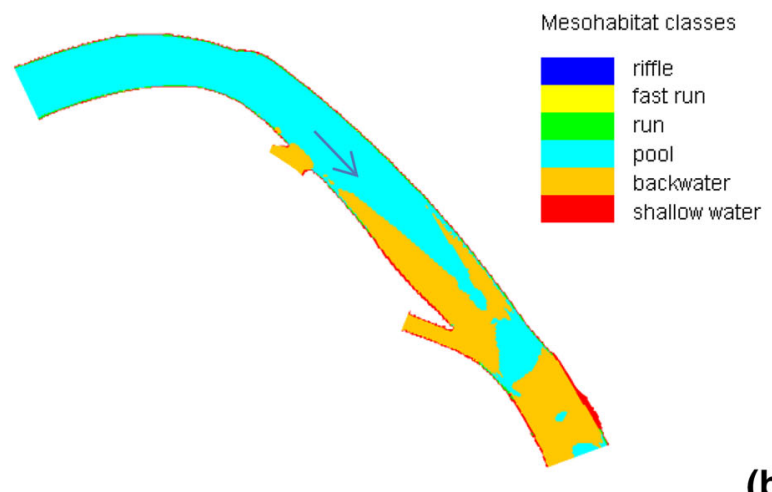

(b)

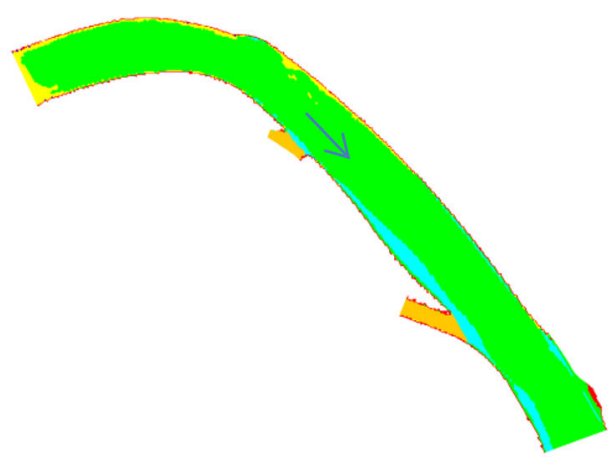

Fig. 7 Distribution of hydro-morphological units based on the MEM approach for a $Q=680 \mathrm{~m}^{3} \mathrm{~s}^{-1}$ and $\mathbf{b} Q=2,375 \mathrm{~m}^{3} \mathrm{~s}^{-1}$

during low flow conditions ( $61 \%$ classified as pool and $33 \%$ classified as backwater). The poor habitat quality has to be related to river regulation and the impact on hydraulics of the downstream hydropower plant (HPP Abwinden-Asten). For instream habitat quality, however, the dynamic component is of special importance (Hauer, 2013). Therefore, an additional high-flow situation has been evaluated concerning the mesohabitat distribution. The modelling results presented in Fig. $7 \mathrm{~b}$ show a change in the distribution mainly from pool and backwater habitat to a so called run hydromorphological unit with obviously higher flow velocities (90\% higher than $0.5 \mathrm{~m} \mathrm{~s}^{-1}$ and $65 \%$ higher than $\left.1.0 \mathrm{~m} \mathrm{~s}^{-1}\right)$. Only the harbour itself was still classified as a backwater habitat with some pool habitat characteristics at the upstream and downstream sites.

Two important issues could be figured out based on this analysis. First, that the harbour, which should be excavated, contains backwater habitat features for both low- and high-flow conditions. Hence, the harbour provides hydraulically stable habitats for stagnophilic aquatic organisms and may also provide sheltered habitat conditions during high flows. The second issue is that the evaluation of the present habitat status may be compared with the stage after implementing the measure (excavation and dumping of the dredged material) which may change habitat composition in terms of changes to the river bathymetry due to the aggradation of dumped material. This is of special importance in (large) river systems as occasionally bottleneck habitats may be disturbed in the mid- to long-term range (e.g. erosion of material and deposited at spawning sites).

High-resolution monitoring of the dredging and dumping event

The dredging survey was performed during 2 days (23. and 24. July 2008) at a discharge of about 2,375 $\mathrm{m}^{3} \mathrm{~s}^{-1}$ (Fig. 8). The increased flow conditions (MQ = $1,480 \mathrm{~m}^{3} \mathrm{~s}^{-1}$ ) resulted in a comparatively high natural suspended sediment concentration of about $200 \mathrm{mg} \mathrm{l}^{-1}$. The fine sediments $\left(d_{50}=0.034 \mathrm{~mm}\right)$ were extracted at the harbour mouth applying a bucket excavator and were loaded on a split hopper barge with a capacity of $400 \mathrm{~m}^{3}$. Subsequently the excavated material was dumped into the main channel of the Danube River in vicinity of the harbour at river-km 2,131.7. In the course of eight dumping operations, 


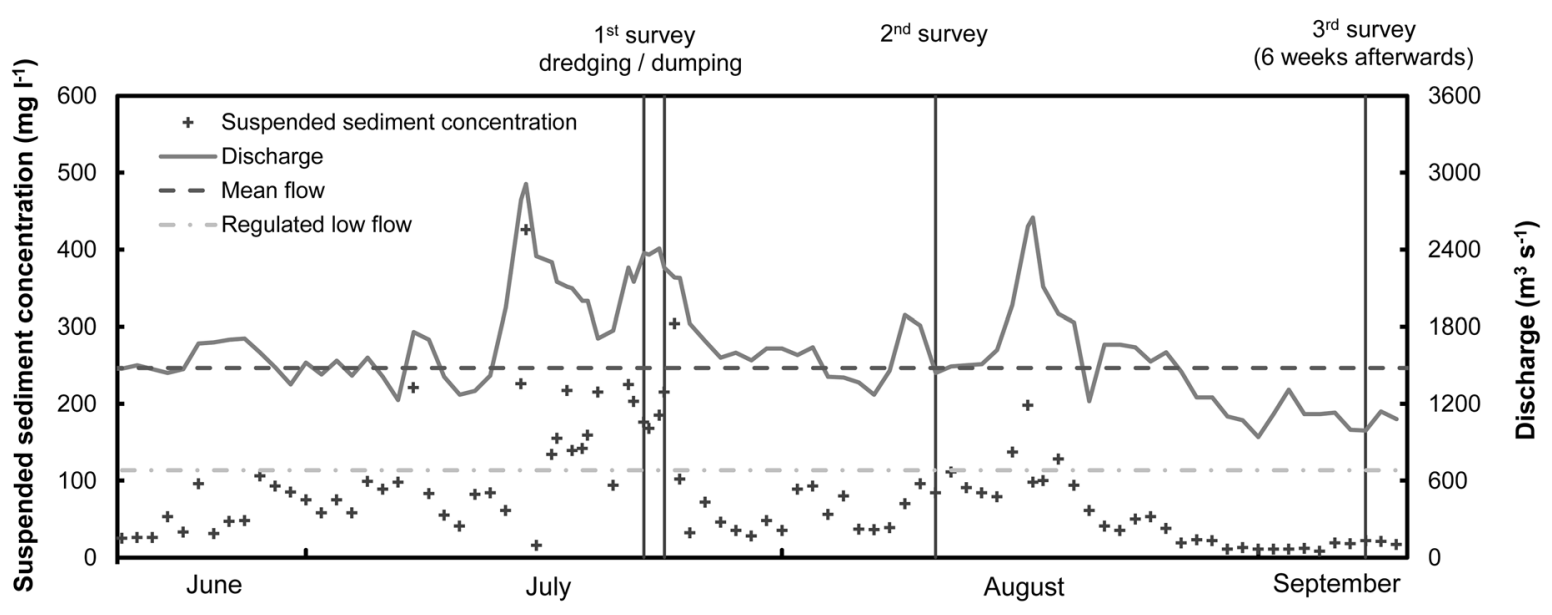

Fig. 8 Measured suspended sediment concentration (cross) and discharge (dark grey solid line) during the surveys as well as mean flow (dashed line) and regulated low flow (dash-dotted line) at the Danube River

material amounting to about $3,200 \mathrm{~m}^{3}$-corresponding to $0.1 \%$ of the mean annual suspended load of the Danube River (Nachtnebel et al., 2004)-was added to the main stream of the Danube River. To simulate the worst-case scenario, the sediment was not dumped while the vessel was in motion, but the barge was opened with maximum speed at a fixed position in the main stream of the river.

The ADCP measurements performed during the excavation work at the harbour entrance and up to $300 \mathrm{~m}$ downstream with a maximum distance of $45 \mathrm{~m}$ from the right bank resulted in depth-averaged flow velocities of $0.91 \mathrm{~m} \mathrm{~s}^{-1}\left(\mathrm{SD} \pm 0.28 \mathrm{~m} \mathrm{~s}^{-1}\right)$. The flow velocities determined by ADV measurements close to the river bed (distance from the river bed $<6 \%$ of the water depth) varied between 0.35 and $0.53 \mathrm{~m} \mathrm{~s}^{-1}$. At the disposal site (stream-km 2,131.7-2,131.3), the flow velocities were comparatively higher with near bed velocities of $0.9 \mathrm{~m} \mathrm{~s}^{-1}$ $\left(\mathrm{SD} \pm 0.14 \mathrm{~m} \mathrm{~s}^{-1}\right)(\mathrm{ADV})$, and depth-averaged flow velocities determined by $\mathrm{ADCP}$ measurements of $1.35 \mathrm{~m} \mathrm{~s}^{-1}\left(\mathrm{SD} \pm 0.16 \mathrm{~m} \mathrm{~s}^{-1}\right)$. The measured ADCP cross-sections comprised the width of the plume (in the navigation channel) but excluded the areas along the river banks.

The suspended sediment measurements applying an ADCP combined with water samples revealed that the impact on the extent and concentration of the resulting suspended sediment plume in the Danube River itself was much higher during dumping the fine sediments than during dredging. The extent of the plume caused by dredging was limited to the right bank with a width less than $50 \mathrm{~m}$ and to a maximum distance from the harbour entrance between 50 and $300 \mathrm{~m}$ during all eight performed dredging operations. Within this area, the concentrations increased from $200 \mathrm{mg} \mathrm{l}^{-1}$ (background concentration) to a maximum of $250 \mathrm{mg} \mathrm{l}^{-1}$ (increase of 25\%) in the water column and $700 \mathrm{mg} \mathrm{l}^{-1}$ (increase of $250 \%$ ) near the bed. Furthermore, the concentration remained relatively constant during the dredging but decreased rapidly after termination of the work. Although obtained by surveys from coastal and estuarine areas, similar observations were described by Fettweis et al. (2011) and Collins (1995), where the suspended sediment concentrations were greater near the bottom compared with those in the water column and rapidly decreased with distance from the dredge.

At the disposal site, an increase in suspended sediment concentration was measured with maximum concentrations of about $500 \mathrm{mg} \mathrm{l}^{-1}$ (increase of $150 \%$ ) in the water column and $3,000 \mathrm{mg} \mathrm{l}^{-1}$ (increase of $1,400 \%$ ) near the bed a short time after the material was unloaded (Fig. 9a). The extension of the plume was limited to a maximum length of $640 \mathrm{~m}$ and the width ranged from $50 \mathrm{~m}$ to $170 \mathrm{~m}$, but it never reached the banks. Figure 9a shows the limited spatial extent of the suspended sediment plume-detected by four cross-sectional transects and a subsequent longitudinal ADCP measurement-caused by dumping the fine sediment. The longitudinal measurement demonstrates that even half an hour after the dumping took place, the concentration at the dumping location was higher than the natural concentration indicating that at 
Fig. 9 Measurement of a the distribution of the suspended sediment concentration in four crosssections (CS 1-4) and one longitudinal section (LS 1) and $\mathbf{b}$ the temporal variability $(1 \mathrm{~h})$ of the suspended sediment concentration at a fixed position at river-km 2,131.5 after dredged material disposal in the main stream of the Danube River applying an ADCP combined with water samples (triangles)

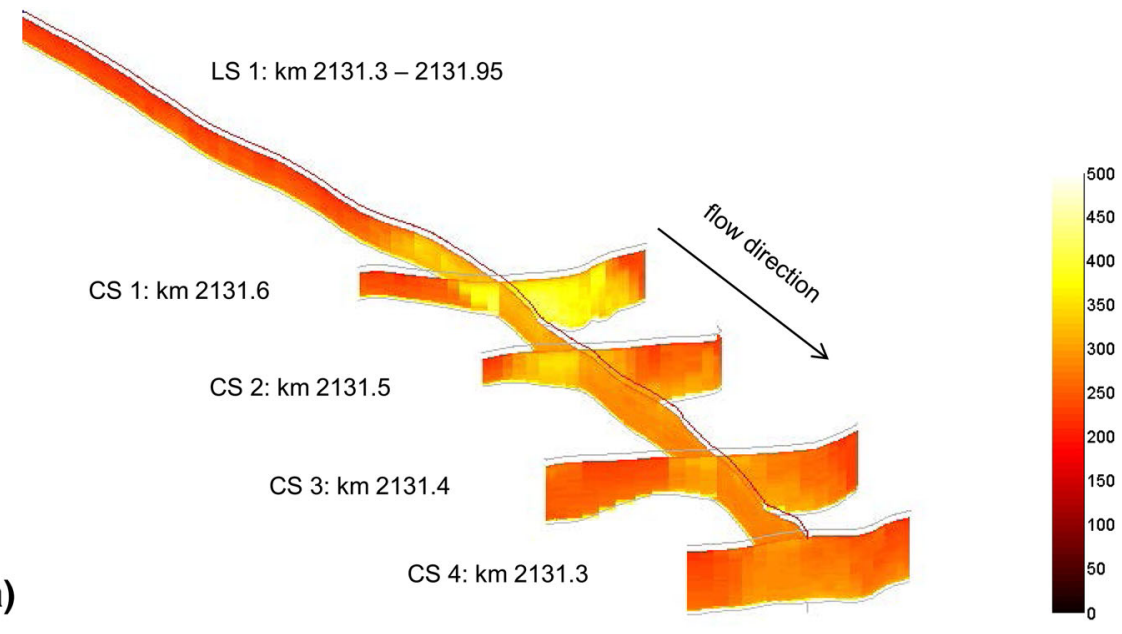

(a)

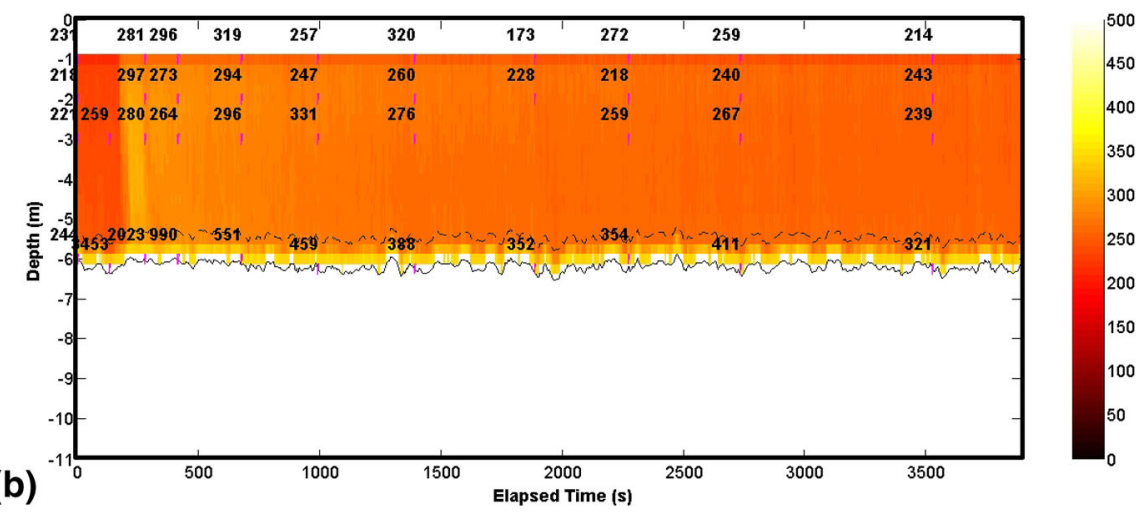

this instant of time not all the dumped material had been transported further downstream. Figure $9 b$ depicts the variation of the concentration at a fixed position in the middle of river-km 2,131.5, $200 \mathrm{~m}$ downstream of the dumping site. The concentration at this position increased sharply within a few minutes, after the barge was opened ( $<5 \mathrm{~min}$ ) but the artificial plume also faded rapidly and could only be detected until 1 hour after the disposal.

Monitoring and modelling of the post-dumping stage

The multi-beam echosounder measurements before the dredging/disposal procedure (evening of the 22. July 2008) were compared with those after the work (evening of the 23. and 24. July 2008, respectively) to identify the morphological changes. At the dredging site, an area of about $4,000 \mathrm{~m}^{2}$ material was removed amounting to approximately $3,200 \mathrm{~m}^{3}$ of excavated material. At the disposal site, no increase in bed elevation due to the insertion of the material in the main stream of the Danube was measured within the accuracy of the multibeam echosounder measurements. These results indicate that at a discharge of $2,375 \mathrm{~m}^{3} \mathrm{~s}^{-1}$ (representing a mean flow velocity of $1.42 \mathrm{~m} \mathrm{~s}^{-1}$ and near bed velocities of $0.98 \mathrm{~m} \mathrm{~s}^{-1}$ at the disposal site) and bed shear stresses of 10-12 $\mathrm{N} \mathrm{m}^{-2}$ (determined by RSim3D simulations) at the disposal site (Fig. 10b), no longterm deposition occurs at minimum up to an amount of dumped material of $400 \mathrm{~m}^{3}$ per barge and $1,600 \mathrm{~m}^{3}$ per day, respectively. Figure $10 \mathrm{~b}$ furthermore depicts the heterogeneity of bed shear stress in the study reach (at a discharge of $2,375 \mathrm{~m}^{3} \mathrm{~s}^{-1}$ ) where the influence of the reservoir of the downstream hydropower plant leads to a reduction in bed shear stresses in the downstream half of the reach. Thus, not only the comparatively high discharge during the maintenance work but also the proper selection of the dumping location led to the erosion and the further transport of the material during the course of 1 day. At lower discharges, the bed shear stress decreases (e.g. regulated low flow, Fig. 10a) and 


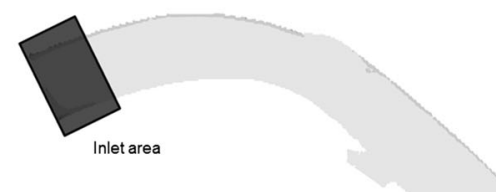

Bed shear stress [N/m2]

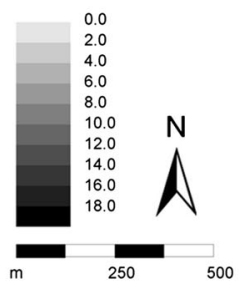

(a)

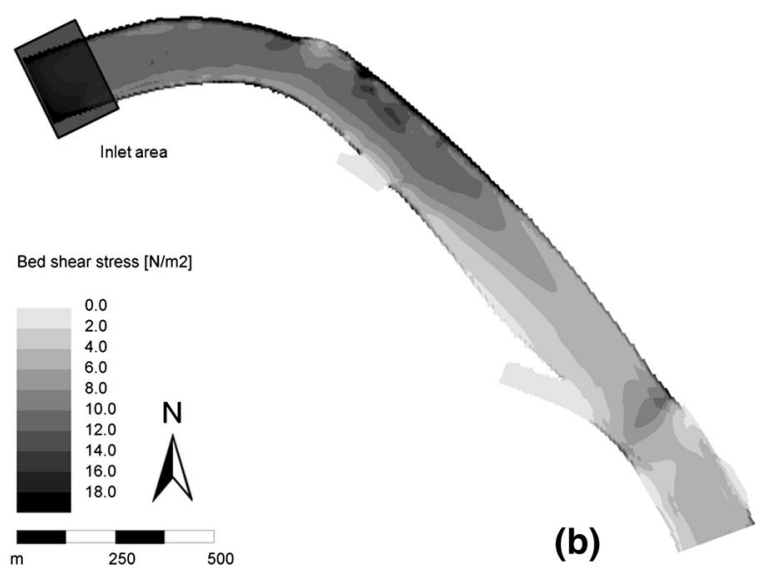

Fig. 10 Distribution of modelled bed shear stress for $\mathbf{a} Q=680 \mathrm{~m}^{3} \mathrm{~s}^{-1}$ and $\mathbf{b} Q=2,375 \mathrm{~m}^{3} \mathrm{~s}^{-1}$

might reach values where no or only slight erosion occurs. Thus, no sediment should be dumped at low flow conditions to avoid depositions that might cause negative ecological effects, e.g. reducing densities and relative abundances of many taxa of benthic macroinvertebrates (Koel \& Stevenson, 2002; Moog et al., 2015).

Two additional field surveys (Fig. 8) were conducted two and 6 weeks after the dredging/dumping operations to obtain calibration and validation data for the numerical modelling at different discharges. These surveys were in temporal accordance with the investigations on benthic invertebrates performed by a team of ecological experts (Moog et al., 2015). The ecological survey comprised the dredging and the dumping site as well as two profiles 300 and $600 \mathrm{~m}$ downstream of the disposal location. To investigate if and to what extent the benthic invertebrate community was disturbed, an air-lift-sampler and a grab sampler were applied during five sampling campaigns, one before and four after excavating and dumping.

Modelling short- to mid-term developments of ecological impacts

Here, numerical sediment transport modelling has been applied following the conceptual modelling design (Fig. 1). As the monitoring of the presented case study revealed that the extent of the plume due to the disposal on the dredged material was much greater than due to dredging, especially the plume caused by dumping was of interest for the modelling. To simulate the sediment input caused by dumping, it was assumed that the dumped material first settles to the river bed, and afterwards the deposits are consequently eroded. This hypothesis is based on the monitoring results which revealed that the concentrations at the dumping site near the bed were about six to ten times higher than the concentrations in the water body, and that about half an hour after the dumping took place the concentrations at the disposal site were still higher than the natural concentration (Fig. 9). For the performance of the numerical simulations, a time period of $1 \mathrm{~h}$ was chosen as this corresponds with the time needed for loading the barge and thus represents the interval between the dumping operations.

Table 2 summarizes the comparison between measured (combination of acoustically inferred and physically sampled concentrations) and modelled maximum depth-averaged concentration that occurred within $1 \mathrm{~h}$ after the dumping took place, the mean depth-averaged concentration in this hour and the depth-averaged concentration after $1 \mathrm{~h}$ at river-km $2,131.5$ and 2,131.4. For the listed parameters, the deviation of the modelled from the monitored results is less than $\pm 15 \%$ indicating a good agreement between the measurements and numerical modelling.

The comparison between modelled critical shear stress (after Shields, 1936) and bed shear stress (Table 3) highlights that at a discharge of $2,375 \mathrm{~m}^{3} \mathrm{~s}^{-1}$, the bed shear stress $\left(\tau_{\text {crit }}=11.3 \mathrm{Nm}^{-2}\right)$ exceeds by far the critical shear stress $\left(\tau_{\text {crit }}<0.2 \mathrm{Nm}^{-2}\right.$ for grain sizes $<0.2 \mathrm{~mm}$ ) at the dumping location and thus the fine material is eroded and transported further downstream. The layer of the deposited material decreased in thickness by about $50 \%$ within $1 \mathrm{~h}$ of numerical 
Table 2 Comparison of measured and modelled depth-averaged concentrations of the artificial suspended sediment plume and the deviation of the modelled results from the measurements

\begin{tabular}{lllr}
\hline Suspended sediment plume & Measurement results $\left(\mathrm{mg} \mathrm{l}^{-1}\right)$ & Model results $\left(\mathrm{mg}^{-1}\right)$ & Deviation $(\%)$ \\
\hline River-km 2,131.5 & 540 & 560 & 4 \\
Max mean concentration & 290 & 330 & 14 \\
Mean concentration of $1 \mathrm{~h}$ & 260 & 240 & -8 \\
Concentration after $1 \mathrm{~h}$ & & & -7 \\
River-km 2,131.4 & 450 & 320 & -9 \\
Max mean concentration & 300 & 290 & -7 \\
Mean concentration of $1 \mathrm{~h}$ & & 280 & \\
Concentration after $1 \mathrm{~h}$ & & & \\
\hline
\end{tabular}

Table 3 Comparison of modelled bed shear stress $\tau$ (at two locations, river-km 2,131.7 and 2,131.0) and critical shear stress $\tau_{\text {crit }}$ (after Shields, 1936) (grain size $<0.2 \mathrm{~mm}$ ) for four different discharges

\begin{tabular}{llcr}
\hline Discharge $\left(\mathrm{m}^{3} \mathrm{~s}^{-1}\right)$ & $\tau_{\text {crit }}\left(\mathrm{Nm}^{-2}\right)$ & $\tau_{2131.7}\left(\mathrm{Nm}^{-2}\right)$ & $\tau_{2131.0}\left(\mathrm{Nm}^{-2}\right)$ \\
\hline 2,375 & $<0.2$ & 11.3 & 5.5 \\
1,480 & $<0.2$ & 4.5 & 2.1 \\
1,000 & $<0.2$ & 2.3 & 1.0 \\
680 & $<0.2$ & 1.1 & 0.5 \\
\hline
\end{tabular}

simulations indicating that the model results correspond with the measurements insofar as for conditions similar to those during dredging and dumping in July 2008 no mid- to long-term depositions ( $>1$ day) of fine sediments occur. Based on such modelling approaches, short- to mid-term developments of the sediment plume can be predicted with an additional and final habitat evaluation at the end of the project.

The evaluation of the post-project stage based on habitat modelling showed no quantitative changes in the (meso-)habitat distribution compared with the preproject stage presented in Fig. 7. All deposited material was eroded and transported downstream. Thus, no significant changes in the river bathymetry could have been detected which may influence the habitat distribution for both the low- and high-flow situation. However, a sensitivity analysis not only on the hydrological condition but also on the dumping position was performed as the location of the dumping can have a substantial influence on the erosion/ deposition behaviour as shown in Table 3, where the bed shear stresses for the different theoretical scenarios are compared. At river-km 2,131.0, the bed shear stresses at the same discharges are considerably lower than at river-km 2,131.7 due to reduced flow velocities and slope. Thus, it was proved that the site of dumping locations and the variability of discharge have an influence on the fine sediment dynamics in the case of artificial dumping.

The already degraded (regulated) river morphology and the related habitats are already in a poor status compared with the natural historical dynamics of the Danube. However, the approach of a post-project evaluation (habitat modelling) is crucial as the dumping of dredged material may not be eroded in the same way like it was presented in this research study, with the consequence of changes in the river bathymetry. What has to be additionally considered in a postproject stage is the option that the eroded material may be deposited in downstream bottleneck habitats, like spawning grounds of rheophilic cyprinids (Chondrostoma nasus or Barbus barbus). However, for this type of post-project habitat analysis, the sediment composition (e.g. distribution of fines) has to be incorporated into the interdisciplinary analysis between the physical environment and the biotic requirements.

\section{Discussion}

To implement the conceptual model (Fig. 1) in the presented study, an extensive monitoring program was 
conducted using acoustic devices, echosounder and water samples. By applying the combined monitoring system, it was possible to obtain data (flow velocity, suspended sediment concentrations, the temporal and spatial extent of the plume and changes in bed morphology caused by dumping the fine sediments) that could not be detected with a single instrument.

ADCPs provide immediate results and allow a realtime determination of the extent and diffusion of the plume created by the dredge and disposal based on the intensity of the backscatter (Cutroneo et al., 2012). Using water samples to calibrate the ADCP signal has the disadvantage that no in situ calibration of the signal is possible as these water samples have to be analysed in the lab. One option to perform a rough calibration of the ADCP signals in real-time is the use of optical backscatter sensors (Aardom, 2006). As the signals of optical devices are not only dependent on suspended sediment concentration but also on the size, composition and shape of the particles (Gippel, 1995; Czuba et al., 2014), this first calibration can then be optimized by means of the laboratory results of suspended sediment concentration and particle size distribution of the water samples during post-processing. Furthermore, optical sensors can be used to observe the compliance of pre-defined thresholds (Cutroneo et al., 2012) and thus be able to stop the measures in time when these values are exceeded to prevent harmful impacts on the aquatic environment. Optical sensors seem to be an essential supplement to the integrated monitoring approach applied during the field survey. Based on the detailed monitoring in the ecologically oriented conceptual approach, important data concerning future sediment management at the Danube could be derived.

In their strategy developed for coral communities, Orpin et al. (2004) argue that the natural variability of the system could be used to define the limits of acceptable turbidity levels for the present species during dredging or disposal operations. Such an approach assumes that a short-term increase (several hours) that falls within the range of natural variability will not have any significant ecological effect (Fettweis et al., 2011). Although the concentrations caused by dumping the fine sediments considerably exceed the mean annual suspended sediment concentration of $45 \mathrm{mg} \mathrm{l}^{-1}$ (Nachtnebel et al., 2004) of the Austrian Danube River, these values are still lower than the concentration of $15,000 \mathrm{mg} \mathrm{l}^{-1}$ which was measured during the 20-year flood event of August 2002 (Nachtnebel et al., 2004). Concentrations of about $3,000 \mathrm{mg} \mathrm{l}^{-1}$ (maximum concentrations measured during the field campaign at Winter harbour Linz) already occur at discharges of $5,000 \mathrm{~m}^{3} \mathrm{~s}^{-1}$ and have a statistical recurrence interval of about five years at the Danube River (measurement site Linz; source: viadonau).

The occurring concentrations $\left(2,000-3,500 \mathrm{mg}^{-1}\right.$ of a duration of a few minutes and concentrations of $300-600 \mathrm{mg} \mathrm{l}^{-1}$ of a duration of up to $1 \mathrm{~h}$ ) are at the lower level of concentrations considered in literature (e.g. Bucher, 2002; Newcombe \& MacDonald, 1991), investigating the influence that increased suspended sediment concentrations have on riverine fish. Based on the highly accurate suspended sediment sampling, it could be detected that the plume had a limited extent (maximum length of 600 and width of $170 \mathrm{~m}$ ) and did not reach the river banks, where fish often take shelter. These results suggest only a slight modification of behaviour (avoiding) or sporadic pathologic appearances (e.g. increased mucus production in gills epithelium) as they can also occur during flood events. Negative effects on the feeding and consequently on the condition of the fish are probably negligible due to the short duration of increased concentrations (Habersack et al., 2009).

The present status of Danube aquatic fauna is heavily impacted due to different anthropogenic pressures such as (i) flood protection, (ii) inland navigation and (iii) hydropower use. Especially inland navigation (e.g. dredging) and hydropower (e.g. deposition in backwaters of HP) exhibit major impacts on the sediment continuum and sediment dynamics. Here, consequences of the disturbed sediment regime are, however, mainly related to bed load deficits (e.g. ongoing river bed incision) and not to increase in the turbidity (or possible substrate clogging), such as it was documented for the dumping of dredged material (Moog et al., 2015). Thus, in a broader ecological perspective, fish may be affected indirectly by the maintenance activities if the amount and composition of their food organisms is altered. A study about the impact of inland harbour excavating and dredged sediment disposal on benthic invertebrates, an important energy source for fish fauna was performed (Moog et al., 2015). The effects were investigated and documented by Moog et al. (2015) based on five sampling campaigns for the presented case study at the 
Danube, one before and four after excavating and dumping. It could be shown that under given conditions, the sediment dumping did not affect the biota due to the sufficiently high minimum flow velocities (1.4 and $\sim 1.0 \mathrm{~m} \mathrm{~s}^{-1}$ near the river bed) that only allowed short-term deposition at the disposal site and therefore prevented a clogging of the natural bed sediment. During the study, however, it became evident that the excavation of harbour sediment had an effect on the biota leading to a decline of $82 \%$ of the benthic invertebrate biomass as consequence of the maintenance operations (Moog et al., 2015). Based on a rough trend line analysis, a recovery time (return of the impaired area to pre-operation conditions) for the harbour bottom fauna of approximately 235 days was determined.

However, in other studies, dredging and disposal effects (at estuaries and coasts) were found to be site specific (Ware et al., 2010) and when assessing the potential environmental effects, the characteristics of the sediment being deposited, the mode of disposal, timing of the works, volume to be disposed and frequency of the disposal activity are important aspects to consider (Bolam et al., 2006); so the findings of the presented study and the work of Moog et al. (2015) are not generally applicable. To be able to develop recommendations or guidelines for an optimized dredging and dumping procedure, the effects at different boundary conditions must be known. Thus, within the conceptual framework, numerical modelling has been applied to simulate the suspended sediment transport induced by the insertion of the fine material in the main stream of the Danube River. The occurring plume could be reproduced in terms of duration and suspended sediment concentration by the model iSed, but there is still a need to improve and further develop the numerical model.

The applied numerical model determines the suspended sediment transport and the deposition and erosion flux between the bed and the flowing medium for each grain size fraction individually. This is crucial as the percentage of dumped material that is deposited (coarse fraction) and material that goes immediately into suspension or into resuspension (first deposited on the bed and then remobilized) and is transported further downstream (fine fraction: silt and clay), is very much dependent on the grain size distribution. Consequently, the grain size distribution (besides the mode of disposal, timing of the works, volume to be disposed and frequency of the disposal activity) affects the evolution of the river bed and the artificial plume during dumping operations. But with decreasing particle size, electrostatic attraction between the particles gets more dominant than gravitational forces, which leads to cohesive behaviour (Mehta et al., 1989). Based on the above facts, the size of the individual grain becomes less important since coagulation and formation of flocs dominates with cohesive suspended sediments (Droppo et al., 1998). However, these characteristics are in conflict with the grain fraction separated calculation scheme of the applied numerical model and/or numerical modelling in general, and the cohesion of the bed particles is not considered sufficiently by the mathematical formulations of van Rijn (1984) and Garcia \& Parker (1991) that are implemented in the numerical model iSed for sediment exchange with the bed. As the grain size of the excavated material had a $d_{50}$ of $0.034 \mathrm{~mm}$ and a $d_{90}$ of $0.142 \mathrm{~mm}$, respectively, it is expected that consideration of cohesiveness would yield more accurate results.

Moreover, the behaviour of the sediment immediately after the opening of the barge and the insertion in the water could not be investigated within this study, but is crucial for ecologically oriented monitoring concepts. More information about the settling velocity, the drift and the proportion of material that does not settle down but goes directly into suspension are necessary and should be gained by detailed large-scale lab investigations. A better understanding of this process would further facilitate achieving more accurate modelling results in the future.

\section{Conclusions}

Based on the findings of the presented study and the discussion on the scope of the derived conceptual model, it can be concluded that both integrated monitoring and modelling approaches are recommended for instream harbour dredging, especially in large river systems. The preliminary habitat modelling work is of great importance for determining the habitat quality of the areas of dredging and possible dumping and if, due to erosion and downstream transport, crucial (bottleneck) habitats like spawning sites are impacted. Moreover, accurate and high-resolution monitoring of suspended sediment concentration is 
required due to the fact that certain thresholds, e.g. harmful impacts on the fish zoonosis, may be exceeded and hence the dumping has to be stopped immediately. Moreover, the development of the plume and deposits on the river bed is of great importance. Here, highresolution bathymetry measuring systems have to be applied in the post-placement stage. Alternatively, numerical models can be used for calculating the short- to mid-term development of the sediment deposits. A final integrated evaluation based on numerical habitat modelling (using target species), in which the meso-unit scale is recommended, should be performed at the end of the entire monitoring program.

The results of the presented study furthermore not only highlight the operative range but also limit where and when disposal of fine material in a river is not possible or should not be performed. As dredging always yields an impact on the environment (e.g. decline in benthic biota), the frequency and the amount of dredging should be kept to an absolute minimum required to guarantee a minimum navigable depth and access to harbours for navigation. When selecting a dumping location, it has to be considered that negative impacts on sensitive habitats (e.g. spawning places, scour holes), at the dumping location itself and further downstream, should be prevented. In general, long-term deposition due to dumping should be avoided; hence the location and the amount of dumped material should be adjusted to the present flow conditions. Generally, higher discharges are favoured for the performance of sediment disposals as they induce higher flow velocities and bed shear stresses, thus the further transport of the dumped material is enhanced. At discharges where the flow velocities and bed shear stresses are too low, so that no or only an insufficient transport of the material occurs, no dumping should be performed.

Acknowledgments Open access funding provided by University of Natural Resources and Life Sciences Vienna (BOKU). The authors would like to thank the following institutions for funding this research work: viadonau; Federal Ministry for Transport, Innovation and Technology; Federal Ministry of Agriculture, Forestry, Environment and Water Management; Verbund Hydropower (VHP); Province of Lower Austria; Province of Upper Austria; Ennshafen GmbH. Furthermore, the financial support by the Federal Ministry of Economy, Family and Youth and the National Foundation for Research, Technology and Development is gratefully acknowledged. The authors thank the staff of the hydrographical and hydrological departments of viadonau for their participation in field measurements as well as the colleagues Franz Böck, Philipp Gmeiner, Marcel Liedermann and Bernhard Schober for their assistance.

Open Access This article is distributed under the terms of the Creative Commons Attribution 4.0 International License (http:// creativecommons.org/licenses/by/4.0/), which permits unrestricted use, distribution, and reproduction in any medium, provided you give appropriate credit to the original author(s) and the source, provide a link to the Creative Commons license, and indicate if changes were made.

\section{References}

Aardom, J. H., 2006. Quantification of sediment concentrations and fluxes from ADCP measurements, IXèmes Journées Nationales Génie Civil - Génie Côtier, 12-14 September 2006, Brest: 501-510.

Ashmore, P. \& M. Church, 2001. The impact of climate change on rivers and riverprocesses in Canada. Geological Survey of Canada, Bulletin 555: 58.

Austrian Federal Waterways Authority, 1997. Die kennzeichnenden Wasserstände der österreichischen Donau (KWD 1996). Austrian Federal Waterways Authority, Vienna.

Bai, Y., Z. Wang \& H. Shen, 2003. Three-dimensional modelling of sediment transport and the effects of dredging in the Haihe Estuary. Estuarine, Coastal and Shelf Science 56: 175-186.

Baranya, S. \& J. Józsa, 2013. Estimation of suspended sediment concentrations with ADCP in Danube River. Journal of Hydrology and Hydromechanics 61(3): 232-240.

Bolam, S. G., H. L. Rees, P. Somerfield, R. Smith, K. R. Clarke, R. M. Warwick, M. Atkins \& E. Garnacho, 2006. Ecological consequences of dredged material disposal in the marine environment: a holistic assessment of activities around the England and Wales coastline. Marine Pollution Bulletin 52: 415-426.

Bucher, R., 2002. Feinsedimente in schweizerischen Fliessgewässern - Einfluss auf Fischbestände. Fischnetz-Publikation. EAWAG, Dübendorf.

Collins, T. R., 1995. Dredging induced near-field resuspendedsediment concentrations and source strength. Misc. paper D-95-2, U.S. Army Engineer Waterways Experiment Station, Vicksburg, MS.

Cutroneo, L., M. Castellano, A. Pieracci, P. Povero, S. Tucci \& M. Capello, 2012. The use of a combined monitoring system for following a turbid plume generated by dredging activities in a port. Journal of Soils and Sediments 12: 797-809.

Cutroneo, L., M. Castellano, M. P. Ferranti, P. Povero, S. Tucci $\&$ M. Capello, 2013. Use of optical and acoustic instruments to study the turbid plumes generated by three different types of dredges during dredging activities inside and outside of a port. Journal of Soils and Sediments 13: 1645-1654.

Czuba, J. S., T. D. Straub, C. A. Curran, M. N. Landers \& M. M. Domanski, 2014. Comparison of fluvial suspendedsediment concentrations and particle-size distributions 
measured with in-stream laser diffraction and in physical samples. Water Resources Research, 51, 320-340.

Darby, S. E. \& C. R. Thorne, 1995. Fluvial maintenance operations in managed alluvial rivers. Aquatic Conservation. Marine and Freshwater Ecosystems 5: 37-54.

Deines, K. L., 1999. Backscatter Estimation Using Broadband Acoustic Doppler Current Profilers. In: Oceans 99 MTS/ IEEE Conference Proceedings, San Diego, pp. 249-253.

Droppo, I. G., D. Jeffries, C. Jaskot \& S. Backus, 1998. The prevalence of freshwater flocculation in cold regions: a case study from the mackenzie River Delta, Northwest Territories. Canada. Arctic 51(2): 155-164.

Edwards, T. \& G. Glysson, 1999. Field methods for measurement of fluvial sediment. Techniques of Water-Resources Investigations of the U.S. Geological Survey, Book 3, Application of Hydraulics, Chapter C2. Reston, Virginia.

Fettweis, M., M. Baeye, F. Francken, B. Lauwaert, D. Van den Eynde, V. Van Lancker, C. Martnes \& T. Michielsen, 2011. Monitoring the effects of disposal of fine sediments from maintenance dredging on suspended particulate matter concentration in the Belgian nearshore area (southern North Sea). Marine Pollution Bulletin 62: 258-269.

Francois, R. E. \& G. R. Garrison, 1982a. Sound absorption based on ocean measurements. Part I: Pure water and magnesium sulfate contributions. Journal of the Acoustic Society of America 72: 896-907.

Francois, R. E. \& G. R. Garrison, 1982b. Sound absorption based on ocean measurements. Part II: Boric acid contribution and equation for total absorption. Journal of the Acoustic Society of America 72: 1870-1890.

Garcia, M. \& G. Parker, 1991. Entrainment of bed sediment into suspension. Journal of Hydraulic Engineering 117: 414-435.

Gippel, C. J., 1995. Potential of turbidity monitoring for measuring the transport of suspended solids in streams. Hydrological Processes 9: 83-97.

Guerrero, M., N. Rüther, R. Szupiany, S. Haun, S. Baranya \& F. Latosinski, 2016. The acoustic properties of suspended sediment in large rivers: consequences on ADCP methods applicability. Water 8(1): 13 .

Habersack, H., P. Mayr, R. Gierlinger \& S. Schneglberger, 2000. Mehrdimensionale Abflussmodellierung am der Beispiel Lafnitz. Wiener Mitteilungen Wasser - Abwasser - Gewässer. 165: 1-170.

Habersack, H., O. Moog, C. Wiesner, M. Haimann, I. Stubauer, F. Charousek, F. Böck, C. Frangez, P. Gmeiner, W. Graf, W. Hirth, T. Huber, B. Janecek, P. Leitner, M. Liedermann, K. Moog, B. Müller, J. Radinger, B. Schober, F. Sporka \& M. Tritthart, 2009. Untersuchung der Auswirkungen von Baggerungen und Verklappungen hochwasserbedingter Feinsedimentablagerungen in der Donau am Fallbeispiel Winterhafen Linz. Report, University of Natural Resources and Life Sciences, Vienna.

Hauer, C., 2013. Eco-hydraulic modelling and river morphodynamics in context of the European Water-Management Directives (floods-, water framework-, renewable resources-). Habilitation thesis -Universität für Bodenkultur Wien; Habilitation im Fach Ökohydraulik und Naturnaher Wasserbau.

Hauer, C., 2015. Review of hydro-morphological management criteria on a river basin scale for preservation and restoration of freshwater pearl mussel habitats. Limnologica - Ecology and Management of Inland Waters 50: 40-53.

Hauer, C., G. Mandlburger \& H. Habersack, 2009. Hydraulically related hydro-morphological units: description based on a new conceptual mesohabitat evaluation model (MEM) using lidar data as geometric input. River Research and Application 25(1): 29-47.

Hauer, C., G. Unfer, M. Tritthart, E. Formann \& H. Habersack, 2011. Variability of mesohabitat characteristics in rifflepool reaches: testing an integrative evaluation concept (FGC) for MEM-application. River Research and Application 27(4): 403-430.

Hauschild, A., 2009. Sedimenttransportmodellierung mit Delft3D am Beispiel von Maßnahmen am Rhein. In bgf (ed.) Sedimentologische Prozesse - Analyse, Beschreibung, Modellierung; 11. Gewässermorphologisches Kolloquium, Koblenz, 11-12. November.78-88.

Hohensinner, S., H. Habersack, M. Jungwirth \& G. Zauner, 2004. Reconstruction of the characteristics of a natural alluvial river-floodplain system and hydromorphological changes following human modifications: The Danube River (1812-1991). River Research and Applications 20: 25-41.

Je, C., D. F. Hayes \& K. Kim, 2007. Simulation of resuspended sediments resulting from dredging operations by a numerical flocculent transport model. Chemosphere 70 : 187-195.

Kemp, P., D. Sear, A. Collins, P. Naden \& I. Jones, 2011. The impacts of fine sediment on riverine fish. Hydrological Processes 25: 1800-1821.

Koel, T. M. \& K. E. Stevenson, 2002. Effects of dredge material placement on benthic macroinvertebrates of the Illinois River. Hydrobiologia 474: 229-238.

Maushake, C., 2008. Untersuchungen zur Verdriftung von Baggergut mit ADCP auf einer Klappstelle vor Rügen. In Bundesanstalt für Gewässerkunde (eds), Ultraschall in der Hydrometrie: neue Technik - neuer Nutzen?!; Seminar 3-4 June 2008. Koblenz: 65-75.

Mehta, A. J., E. J. Hayter, W. R. Parker, R. B. Krone \& A. M. Teeter, 1989. Cohesive Sediment Transport. I: Process Description. Journal of Hydraulic Engineering 115(8): 1076-1093.

Mestres, M., J. P. Sierra, C. Mösso, A. Sánchez-Arcilla, M. Hernáez \& J. Morales, 2014. Numerical assessment of the dispersion of overspilled sediment from a dredge barge and its sensitivity to various parameters. Marine Pollution Bulletin 79(2014): 225-235.

Moog, O., I. Stubauer, M. Haimann, H. Habersack \& P. Leitner, 2015. Effects of harbour excavating and dredged sediment disposal on the benthic invertebrate fauna of River Danube (Austria). Hydrobiologia. doi:10.1007/s10750-015-2476-x.

Nachtnebel, H. P., A. Debene, R. A. Herget, P. Flicker, C. Kölbl, H. Schimpf \& L. Grill, 2004. Schwebstoffbilanzierung im Bereich von Stauräumen an der österreichischen Donau, WP Donau TP 02. In Lebensministerium (ed.) Analyse der Hochwasserereignisse vom August 2002-FloodRisk, Technical Report, BMLFUW.

Newcombe, C. P. \& D. D. MacDonald, 1991. Effects of suspended sediments on aquatic ecosystems. North American journal of fisheries management 11: 72-82. 
Orpin, A. R., P. V. Ridd, S. Thomas, K. R. N. Anthony, P. Marshall \& J. Oliver, 2004. Natural turbidity variability and weather forecasts in risk management of anthropogenic sediment discharge near sensitive environments. Marine Pollution Bulletin 49: 602-612.

Owens, P. N., R. J. Batalla, A. J. Collins, B. Gomez, D. M. Hicks, A. J. Horowitz, G. M. Kondolf, M. Marden, M. J. Page, D. H. Peacock, E. L. Petticrew, W. Salmons \& N. A. Trustrum, 2005. Fine-grained sediment in river systems: environmental significance and management issues. River Research and Application 21: 693-717.

Paarlberg, A. J., M. Guerrero, F. Huthoff \& M. Re, 2015. Optimizing dredg-and-dump activities for river navigability using a hydro-morphodynamik model. Water 7: 3943-3962.

Patankar, S. V. \& D. P. Spalding, 1972. A calculation procedure for heat, mass and momentum transfer in three-dimensional parabolic flows. International Journal of Heat And Mass Transfer 15: 1787-1806.

Prosser, I. P., I. D. Rutherford, J. M. Olley, W. J. Young, P. J. Wallbrink \& C. J. Moran, 2001. Large-scale patterns of erosion and sediment transport in river networks, with examples from Australia. Marine and Freshwater Research 52: 81-99.

Prazan, H., 1990. Über Schwebstoffablagerungen in den Stauräumen der Donaukraftwerke in Österreich. (Sedimentdepositions in the resevoirs of the "Danube Hydro, Austria"). Österreichische Wasserwirtschaft 42: 73-84.

Reichel, G. \& H. P. Nachtnebel, 1994. Suspended sediment monitoring in a fluvial environment: advantages and limitations applying an acoustic Doppler current profiler. Water Research 28: 751-761.

Shields, A., 1936. Application of similarity principles and turbulence research to bed-load movement. Mitteilung der Preussischen Versuchsanstalt für Wasserbau und Schiffbau, 26.

Thevenot, M. M., T. L. Prickett \& N. C. Kraus, 1992. Tylers Beach, Virginia, Dredged Material; Plume Monitoring Project 27 September to 4 October 1991. Technical Report.

Tritthart, M., 2005. Three-dimensional numerical modelling of turbulent river flow using polyhedral finite volumes. Vienna University of Technology, Austria. Wiener Mitteilungen Wasser-Abwasser-Gewässer 193: 1-179.

Tritthart, M. \& D. Gutknecht, 2007. Three-dimensional simulation of free-surface flows using polyhedral finite volumes. Engineering Applications of Computational Fluid Mechanics 1: 1-14.

Tritthart, M., C. Hauer, M. Liedermann \& H. Habersack, 2008. Computer-aided mesohabitat evaluation, part II - model development and application in the restoration of a large river. [River Flow 2008, Cesme-Izmir, 3.-5.9.2008] In: Altinakar, M.S., Kokpinar, M.A., Darama, Y., Yegen, E.B., Harmancioglu, N. (eds), International Conference on Fluvial Hydraulics: 1885-1893.

Tritthart, M., B. Schober, M. Liedermann \& H. Habersack, 2009. Development of an integrated sediment transport model and its application to the Danube River. In Water Engineering for a sustainable Environment; Proceedings of 33rd IAHR Congress, pp. 876-883.

Tritthart, M., B. Schober \& H. Habersack, 2011. Non-uniformity and layering in sediment transport modelling 1: flume simulations. Journal of Hydraulic research 49(3): 325-334.

van Rijn, L. C., 1984. Sediment transport, Part II: suspended load transport. Journal of Hydraulic Engineering, ASCE 110(12): 1613-1641.

Walling D. W., 2005. Tracing suspended sediment sources in catchments and river systems. Science of the Total Environment 344: 159-184.

Walling, D. E. \& D. Fang, 2003. Recent trends in the suspended sediment loads of the world's rivers. Global and Planetary Change 39: 111-126.

Walling, D. E. \& B. W. Webb, 1987. Suspended load in gravelbed rivers: UK experience. In Thorne, C.R., Bathurst, J.C., Hey, R.D., (eds), Sediment Transport in Gravel-bed Rivers. Wiley: 691-723.

Ware, S., S. G. Bolam \& H. L. Rees, 2010. Impact and recovery associated with the deposition of capital dredgings at UK disposal sites: Lessons for future licensing and monitoring. Marine Pollution Bulletin 60(2010): 79-90.

Wilber, D. \& D. Clarke, 2001. Biological effects of suspended sediments: a review of suspended sediment impacts on fish and shellfish with relation to dredging activities in estuaries. North American Journal of Fisheries Management 21(4): 855-875.

Wilber, D. \& D. Clarke, 2007. Defining and assessing benthic recovery following dredging and dredged material disposal. In Proceedings XXVII World Dredging Congress 2007, Orlando, FL, pp. 603-618.

Urick, R. J., 1948. The absorption of sound in irregular particles. Journal of the Acoustic Society of America 20(3): 283-289.

Zauner, G., P. Pinka \& O. Moog, 2001. Pilotstudie Oberes Donautal - Gewässerökologische Evaluierung neuges chaffener Schotterstrukturen im Stauwurzelbereich des Kraftwerks Aschach. Studie im Auftrag der Wasserstraßendirektion. 